\section{Wrapping in Polyvinyl Chloride Film Slows Quality Loss of Yellow Passion Fruit}

\author{
Harvey E. Arjona ${ }^{1}$, Frank B. Matta ${ }^{2}$, and James O. Garner, Jr. ${ }^{3}$ \\ Department of Horticulture, Box 9645, Mississippi State University, Mississippi \\ State, MS 39762
}

Additional index words. juice $\mathrm{pH}$, postharvest, sugars, water loss

\begin{abstract}
Vine-ripened yellow passion fruit (Passiflora edulis f. flavicarpa Deg.) were placed in styrofoam trays and wrapped with VF-60 plastic film and stored for 15 and 30 days. Wrapping prevented fruit weight loss while maintaining external appearance. Storage time contributed to quality loss of external appearance. Wrapping maintained fruit glucose and fructose content at 43 and $40 \mathrm{mg} \cdot \mathrm{ml}^{-1}$ up to 15 days, respectively, and did not influence juice $\mathrm{pH}$. Initial sucrose content of wrapped fruit declined $62 \%$ after 15 days in storage. Plastic film did not effectively modify $\mathrm{O}_{2}$ or $\mathrm{CO}_{2}$.
\end{abstract}

Passion fruit stored at 5C and 85\% relative humidity (RH) lost moisture rapidly; $80 \%$ of the fruit surface was shriveled after 3 days in storage (Arjona et al., 1992). While passion fruit juice remained wholesome for 7 days, fruit began shriveling soon after abscission (Knight and Sauls, 1983). The rind accounted for most of the dehydration in the first 15 days of storage (Arjona, 1990). Storing passion fruit in sealed polyethylene bags at 6 to $10 \mathrm{C}$ can protect them from shriveling for 3 to 4 weeks (Campbell and Knight, 1983). Cereda et al. (1976) reported that passion fruit stored in polyethylene bags at $7.2 \mathrm{C}$ and $85 \%$ to $90 \%$ $\mathrm{RH}$ remained marketable up to 30 days. However, moisture condenses on the fruit surface under consistently high $\mathrm{RH}$, creating conditions favorable for pathogen growth (Zagory and Kader, 1988). For fresh-fruit use, water loss that results in wilting and shriveling must be minimized.

Recent studies on modified-atmosphere packaging of horticultural commodities show that highly permeable films such as polyvinyl chloride (PVC) overwraps can maintain postharvest quality by reducing transpiration and respiration (Kader, 1986). The objective of these experiments was to study the effects of PVC film wraps on the quality of stored yellow passion fruit.

\section{Materials and Methods}

Vine-ripened yellow passion fruit provided by J.R. Brooks and Son, Homestead, Fla., were packed on the day of harvest in commer-

Received for publication 17 May 1993. Accepted for publication 13 Nov. 1993. Mississippi Agricultural and Forestry Experiment Station Article no. J7542. The cost of publishing this paper was defrayed in part by the payment of page charges. Under postal regulations, this paper therefore must be hereby marked advertisement solely to indicate this fact.

'Associate Professor, Facultad de Agronomia, Univ. National de Colombia, Bogota, Colombia.

${ }^{2}$ Professor. To whom reprint requests should be addressed.

${ }^{3}$ Professor, cial cardboard boxes (36 individual cell packs) and shipped, via express courier, to our laboratory. Fruit were rinsed with tap water and treated with a $0.5 \%$ sodium hypochloride solution on arrival, i.e., the day after harvest. Four-fruit samples were placed in a $15 \times 15 \times$ 2.5-cm-deep polystyrene tray and overwrapped with a plasticized PVC film (VF-60; Borden Chemical Division, Andover, Mass.). The experiment was a $2 \times 2$ factorial with wrapped and nonwrapped fruit stored at $10 \mathrm{C}$ for 15 or 30 days at $85 \% \mathrm{RH}$. The average fruit weight in each container was $198 \pm 1 \mathrm{~g}$. The treatments were replicated four times (four fruit per replication). Fruit was analyzed immediately on arrival and after treatment with sodium hypochloride as the control. The experiment was conducted twice, starting 15 July and 8 Aug. 1989.

The atmosphere within the packages and in the storage room was sampled $0,5,10,15,20$, 25, and 30 days after storage. A 2-ml sample from wrapped trays was taken with a gas sampling syringe and needle through a neoprene septum $(1.0 \mathrm{~cm}$ in diameter) previously attached to the film. All gas samples were analyzed for $\mathrm{CO}_{2}$ and $\mathrm{O}_{2}$ concentration by means of a gas chromatography fitted with a thermoconductivity detector and a column temperature of $75 \mathrm{C}$.

Fruit were analyzed after 15 and 30 days of storage for the following characteristics: 1)
${ }^{2}$ Expressed as percentage of fruit surface shriveled.

${ }^{\gamma}$ Fruit analyzed immediately on arrival. external appearance (percentage of surface shriveled), 2) weight, 3) pulp percentage (weight of fleshy pericarp and seeds divided by fruit weight $\times 100$ ), 4) juice $\mathrm{pH}, 5$ ) total soluble solids concentration (SSC), and 6) juice fructose, glucose, and sucrose contents determined by high-performance liquid chromatography following the method of Arjona et al. (1992). Fruit weight loss was calculated by subtracting fruit weight at the end of the storage period from the initial weight. Analysis of variance was performed for all variables measured, and LSD tests were used to separate treatment means. Since there was no treatment $x$ experiment interactions for any of the characteristics measured, after analysis, data were pooled over experiments for comparisons of means.

\section{Results and Discussion}

The $\mathrm{CO}_{2}$ concentration within the package never exceeded $0.5 \%$ and that of $\mathrm{O}_{2}$ never dropped below $13 \%$ throughout the 30 days of the experiment. In both experiments, superficial mold growth was observed following 30 days of storage, but the growth was minimal and no fruit were discarded.

Film-wrapped fruit had a better appearance, expressed as percentage of surface shriveled, than nonwrapped fruit (Table 1). Fruit stored for 15 days also had a better appearance than fruit stored for 30 days. After 15 days of storage, $50 \%$ of the surface of nonwrapped fruit shriveled; the percentage of surface shriveled increased to $100 \%$ in nonwrapped fruit stored for 30 days. Nonwrapped fruit had the highest weight loss, and weight loss increased with storage time. Because nonwrapped fruit lost more weight than wrapped fruit, nonwrapped fruit had a higher pulp percentage. Juice $\mathrm{pH}$ was unaffected by any of the treatments. Fruit lost SSC during storage, but there were no differences among treatments. These results agree with those reported by Salazar and Torres (1977), who found that $80 \%$ of the mature passion fruit stored in plastic bags for 14 days at 23C remained marketable. Cereda et al. (1976) also obtained similar results. They found that the storage life of passion fruit could be extended up to 30 days if fruit were treated with paraffin wax or packed in polyethylene bags and stored at $7.2 \mathrm{C}$ and $85 \%$ to $90 \% \mathrm{RH}$.

Initial sucrose and fructose levels in

Table 1. Effect of plastic film and storage duration on external appearance, juice $\mathrm{pH}$, soluble solids concentration (SSC), fruit weight, fruit weight loss, and pulp percentage of yellow passion fruit.

\begin{tabular}{lcccccc}
\hline $\begin{array}{l}\text { Treatment and } \\
\text { days stored }\end{array}$ & $\begin{array}{c}\text { External } \\
\text { appearance }\end{array}$ & $\begin{array}{c}\text { Fruit wt } \\
\text { loss }(\%)\end{array}$ & $\begin{array}{c}\text { Juice } \\
\mathrm{pH}\end{array}$ & SSC & $\begin{array}{c}\text { Fruit wt } \\
(\mathrm{g})\end{array}$ & $\begin{array}{r}\text { Pulp } \\
(\%)\end{array}$ \\
\hline $\begin{array}{l}\text { Initialy } \\
\text { Wrapped }\end{array}$ & $3 \mathrm{~d}^{\mathrm{x}}$ & --- & 3.2 & $15 \mathrm{a}$ & $49 \mathrm{a}$ & $45 \mathrm{~b}$ \\
$\quad$ & & & & & & \\
$\quad 15$ & $7 \mathrm{~d}$ & $7 \mathrm{~d}$ & 3.2 & $11 \mathrm{~b}$ & $47 \mathrm{a}$ & $46 \mathrm{~b}$ \\
30 & $18 \mathrm{c}$ & $14 \mathrm{c}$ & 3.3 & $10 \mathrm{~b}$ & $45 \mathrm{a}$ & $45 \mathrm{~b}$ \\
Nonwrapped & & & & & & \\
$\quad 15$ & $50 \mathrm{~b}$ & $32 \mathrm{~b}$ & 3.3 & $11 \mathrm{~b}$ & $33 \mathrm{~b}$ & $68 \mathrm{a}$ \\
30 & $100 \mathrm{a}$ & $51 \mathrm{a}$ & 3.4 & $12 \mathrm{~b}$ & $25 \mathrm{c}$ & $70 \mathrm{a}$ \\
LSD & 8.2 & 6.4 & $\mathrm{NS}$ & 2.7 & 5.5 & 7.8 \\
\hline
\end{tabular}

${ }^{x}$ Means followed by the same letter within a column do not differ by LSD at $P \leq 0.05$. 
Table 2. Effect of plastic film and storage time on sugar concentration of yellow passion fruit.

\begin{tabular}{lccc}
\hline Treatment and & \multicolumn{3}{c}{ Sugar concn $\left(\mathrm{mg}^{\mathrm{m}} \mathrm{ml}^{-1}\right)$} \\
\cline { 2 - 4 } days stored & Sucrose & Fructose & Glucose \\
\hline Initial $^{z}$ & $32 \mathrm{a}^{y}$ & $47 \mathrm{a}$ & $49 \mathrm{a}$ \\
Wrapped & & & \\
$\quad 15$ & $12 \mathrm{~b}$ & $40 \mathrm{~b}$ & $43 \mathrm{ab}$ \\
30 & $11 \mathrm{~b}$ & $35 \mathrm{bc}$ & $40 \mathrm{~b}$ \\
Nonwrapped & & & \\
$\quad 15$ & $14 \mathrm{~b}$ & $33 \mathrm{c}$ & $40 \mathrm{~b}$ \\
30 & $10 \mathrm{~b}$ & $31 \mathrm{c}$ & $37 \mathrm{~b}$ \\
LSD & 14 & 6 & 6 \\
\hline
\end{tabular}

${ }^{\mathrm{Z}}$ Fruit analyzed immediately on arrival.

${ }^{\gamma}$ Means followed by the same letter within a column do not differ by LSD at $P \leq 0.05$.

wrapped fruit stored for 15 days declined $62 \%$ and $15 \%$, respectively (Table 2). Sucrose content, after an initial drop, remained between 11 and $14 \mathrm{mg} \cdot \mathrm{ml}^{-1}$ regardless of wrapping or days in storage. Fructose content, however, was higher in wrapped fruit stored for 15 days than in nonwrapped fruit stored for 15 or 30 days. The decrease in glucose in wrapped fruit stored for 15 days was nonsignificant. Glucose content of wrapped fruit decreased $18 \%$ from initial measurements after 30 days in storage. The glucose content of nonwrapped fruit stored for 15 or 30 days was similar (Table 2).

In these experiments, wrapping fruit with plasticized film minimized fruit weight loss and maintained the external appearance of stored fruit. RH under the wrapped treatments was not measured, but condensation, which may have contributed to the mold growth, formed in the packages after 25 days of storage. Considering the minor increase in $\mathrm{CO}$ and moderate decrease in $\mathrm{O}_{2}$ under the PVC film in these experiments, much of the beneficial effect of film wrap was from controlling weight loss. The utility of permeable plastic films that would result in higher $\mathrm{CO}_{2}$ and lower $\mathrm{O}_{2}$ levels than we achieved needs investigation in relation to storage of yellow passion fruit.

\section{Literature Cited}

Arjona, H.E. 1990. Postharvest physiology studies of passion fruit (Passiflora edulis Sims). $\mathrm{PhD}$ Diss., Mississippi State Univ., Mississippi State, Miss.
Arjona, H.E., F.B. Matta, and J.O. Garner, Jr. 1992. Temperature and storage time affect quality of yellow passion fruit. HortScience 27:809-810.

Campbell, C.W. and R.J. Knight, Jr. 1983. Producción de granadilla. Comunicación XIII Congress NORCOFEL. Ministerio de Agricultural, Pesca y Alimentación, Canary Islands, Spain. p. 223-231.

Cereda, E., M:P. Cereda, and M.A.M. Brasil. 1976. Concervacão do maracujá amarelo para utilizacão in natura. Acta Hort. 57:145-151.

Kader, A.A. 1986. Biochemical and physiological basis for effects of controlled and modified atmosphere on fruit and vegetables. Food Technol. 40(5):99-104.

Knight, R.J., Jr., and J.W. Sauls. 1983. The passion fruit. Fruit Crop Fact Sheet. FC-160. Florida Coop. Ext. Serv.

Pruthi, J.S. 1963. Physiology, chemistry and technology of passion fruit, p. 203-282. In: Advances in food research. Academic, New York and London.

Salazar, R. and R. Torres. 1977. Almacenamiento de frutos de maracuya en bolsas depolietileno. Revista ICA-Bogota, Colombia. 12:1-11.

Zagory, D. and A.A. Kader. 1988. Modified atmosphere packaging of fresh produce. Food Technol. 42(9):70-77. 